\title{
Study of the influence of compressive strength concrete on columns during the design of a multi-floor building
}

\section{Estudo da influência da resistência à compressão do concreto em pilares no dimensionamento de edifícios}
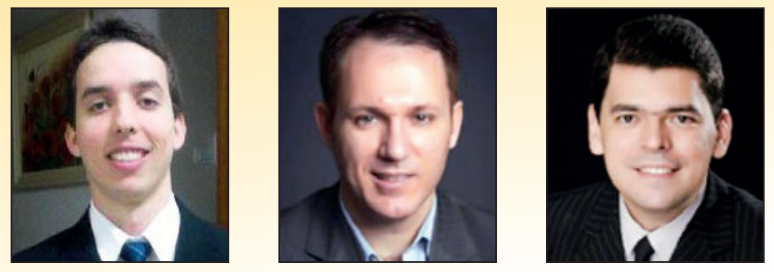

\author{
G. M. FREGONEZI \\ guilherme@fai.com.br \\ https://orcid.org/0000-0001-6177-5609 \\ W. W. WUTZOW a \\ wwwutzow@uem.br \\ https://orcid.org/0000-0002-9103-3769 \\ R. D. VANDERLEI a \\ rdvanderlei@uem.br \\ https://orcid.org/0000-0001-5676-6951
}

\section{Abstract}

This work aims to analyze the influence of the compressive strength of concrete columns in the design of a multi-floor building using the CAD/TQS computational tool. The strengths of the columns varied in increments of $5 \mathrm{MPa}$, from $35 \mathrm{MPa}$ to $90 \mathrm{MPa}$, with a $35 \mathrm{MPa}$ resistance in the remaining structural elements. Analyses of the horizontal deformability, stability parameters, and optimized sections, as well as quantities and cost of the main materials used (concrete, steel, and formwork), were performed. As a result, a $32 \%$ reduction to the total area of the columns was achieved; consequently, a reduction in material quantities and the total cost of the building was also achieved. Thus, greater durability was provided without major costs or loss in structural safety.

Keywords: structural optimization, columns, high-strength concrete.

\section{Resumo}

Este trabalho tem como objetivo analisar a influência da resistência à compressão do concreto em pilares no dimensionamento de um edifício de múltiplos pavimentos, utilizando a ferramenta computacional CAD/TQS. As resistências dos pilares foram variadas em uma razão de $5 \mathrm{MPa}$, de $35 \mathrm{MPa}$ até $90 \mathrm{MPa}$, sendo que os demais elementos estruturais permaneceram com resistências de $35 \mathrm{MPa}$. Foram feitas análises de deformabilidade horizontal, parâmetros de estabilidade, seções otimizadas, além de quantitativos e custos dos principais materiais empregados (concreto, aço e fôrmas). Como resultados, foi possível reduzir em $32 \%$ a área total dos pilares, bem como reduzir quantitativos de materiais e, principalmente, os custos totais do edifício, conferindo maior durabilidade sem maiores custos e, principalmente, sem prejuízo à segurança estrutural.

Palavras-chave: otimização estrutural, pilares, concreto de alta resistência.

State University of Maringá, Department of Civil Engineering, Maringá, PR, Brazil.

Received: 11 Nov 2017 • Accepted: 27 Jun 2018 • Available Online: 


\section{Introduction}

Technological development and the high competitiveness of the current market result in constantly evolving processes. In the construction sector, this fact is reflected in the materials and methods employed, directly affecting one of the most important materials: concrete. Concrete is one of the most widely used materials in this sector since it presents characteristics such as ease of preparation and use, resistance to weather, fire and load effects, low costeffectiveness, etc. However, its behavior is very complex due to its heterogeneous nature. According to Mehta and Monteiro [1], macroscopically concrete can be considered a biphasic material as it is composed of aggregate particles of various shapes and sizes dispersed in a hydrated cement paste. Among the factors that hinder our understanding of this material are the differences between compressive and tensile strengths, the physical non-linearity (considered by strain-stress diagrams), presence of microcracks, water retention, shrinkage, etc. [2].

The response of concrete to applied stresses is not only dependent on the type of stress but also on how the combination of several factors affects the porosity of the different structural components. Factors include properties and proportions of the materials forming the mix, degree of compaction, and cure conditions. From a resistance point of view, the water/cement ratio and the porosity are the most important factors, because, independently of others, they affect the porosity of the cement paste matrix and the transition zone between the matrix and the course aggregate [1].

In recent times, great advancements in concrete resistance have been made due to the amount of studies and investigations into the behavior and properties of the constitutive materials of the mixture. The use of high-strength concrete (HSC) combined with mathematical models of calculations that are closer to the reality brings the possibility of designing bolder buildings and art works with smaller cross-sections whilst respecting the criteria of safety and durability [2]. Among the advantages of HSC are the higher load capacity, smaller aggregate dimensions, reduced column weight, greater lateral rigidity and less axial shortening [3]. Mehta and Monteiro [4] explain that the high strength of HSC is due to the effects of the reduction in porosity, heterogeneity and microcracking in the paste and in the transition zone, therefore presenting a different behavior compared to conventional concrete.

The Euro-International Committee for Concrete and the International Federation for Pre-stressing (CEB-FIP) [5] defines HSC as a concrete with a compressive strength of more than $50 \mathrm{MPa}$. However, the $\mathrm{ACl}$ [6] have recognized that $\mathrm{HSC}$ varies on a geographic basis because, in regions where concrete with 9,000 psi (62 $\mathrm{MPa}$ ) strength is already being commercially produced, for a concrete to be considered high-strength it will have to be in the range of 12,000 to $15,000 \mathrm{psi}(83-103 \mathrm{MPa})$. However, in regions where the limit of commercially produced concrete is $5,000 \mathrm{psi}$ (34 MPa), concrete with 9,000 psi (62 MPa) is considered to be high-strength.

In Brazil, the ABNT NBR 6118: 2014 [7] and the ABNT NBR 8953: 2015 [8] classify concrete structures into two groups of characteristic strength of compression at 28 days $\left(f_{c k, 28 \text { days }}\right)$ : Group I $\left(20 \mathrm{MPa} \leq f_{c k, 28 \text { days }} \leq 50 \mathrm{MPa}\right)$ and Group II ( $\left.55 \mathrm{MPa} \leq f_{c k, 28 \text { days }} \leq 90 \mathrm{MPa}\right)$.
It was only from the last update issued by the Brazilian Standard on design of concrete structures that differences in the equations and considerations for the two strength groups were made. It is important to highlight some of them, which will be explained throughout this study: in the average tensile strength calculations; in the considerations of the shortening strain parameters of the concrete at the beginning of the plastic phase $\left(\varepsilon_{\mathrm{c} 2}\right)$ and concrete shortening strain at the breaking point $\left(\varepsilon_{\mathrm{cu}}\right)$ in the ultimate limit state (ULS) analyses, using the idealized stress-strain diagram; in the calculations of the initial modulus of elasticity $\left(E_{c i}\right)$ and consequently, of secant modulus of elasticity $\left(E_{c s}\right)$; in the value of the fluence coefficient $\phi\left(\mathrm{t}_{\infty}, \mathrm{t}_{0}\right)$, among others.

According to Vanderlei [9], HSC can be obtained with the use of common Portland cement, if adequate measures are taken in the technological control (low water/cement ratios), besides the use of additives, such as slag furnace, silica fume or fly ash. Due to the low water/cement ratios, the use of super plasticizing additives to provide workability to the concrete is of fundamental importance. According to Caldarone [10], the production of HSC does not require exotic materials or special manufacturing processes, but when compared to conventional concrete, the variations in the characteristics and quality of the materials constituting the mix generate significant differences in the final product. All materials must be optimized in the mix in order to achieve maximum strength [11]. According to the literature, HSC may become more fragile due to the potentiation of its characteristics. The desired ductility can be achieved by reducing the maximum spacing between the stirrups by $50 \%$, with a hook inclination of at least $135^{\circ}$ [7], providing the concrete with a passive lateral confinement [2].

The taller and slenderer the building, the greater the load demands present on it, mainly due to horizontal actions. In these cases, global stability analysis and evaluation of the second-order effects become of fundamental importance in the structural design. In general terms, all structures are moveable. In more rigid structures, the displacements resulting from horizontal actions are small, however, in less rigid structures such displacements are so relevant that if they are not correctly considered they can lead to the collapse of the structure.

In this context, the objective of this work is to analyze the influence of the increase in the compression strength of concrete $\left(f_{c k}\right)$ and the reduction of the columns' cross-section on the horizontal deformability, global stability and material consumption (concrete, steel and formwork) of a multi-story building through a computational tool.

\section{Materials and methods}

With the purpose of analyzing the influence of the increase in the compression strength of concrete on columns in terms of displacement, the global stability parameters and on material and labor consumption, a multi-story residential building and the CAD/TQS computational tool were adopted.

\subsection{Structural model}

The building studied consists of a ground floor, sixteen standard floor and water tank, with a total height of 61.75 meters above ground level. 


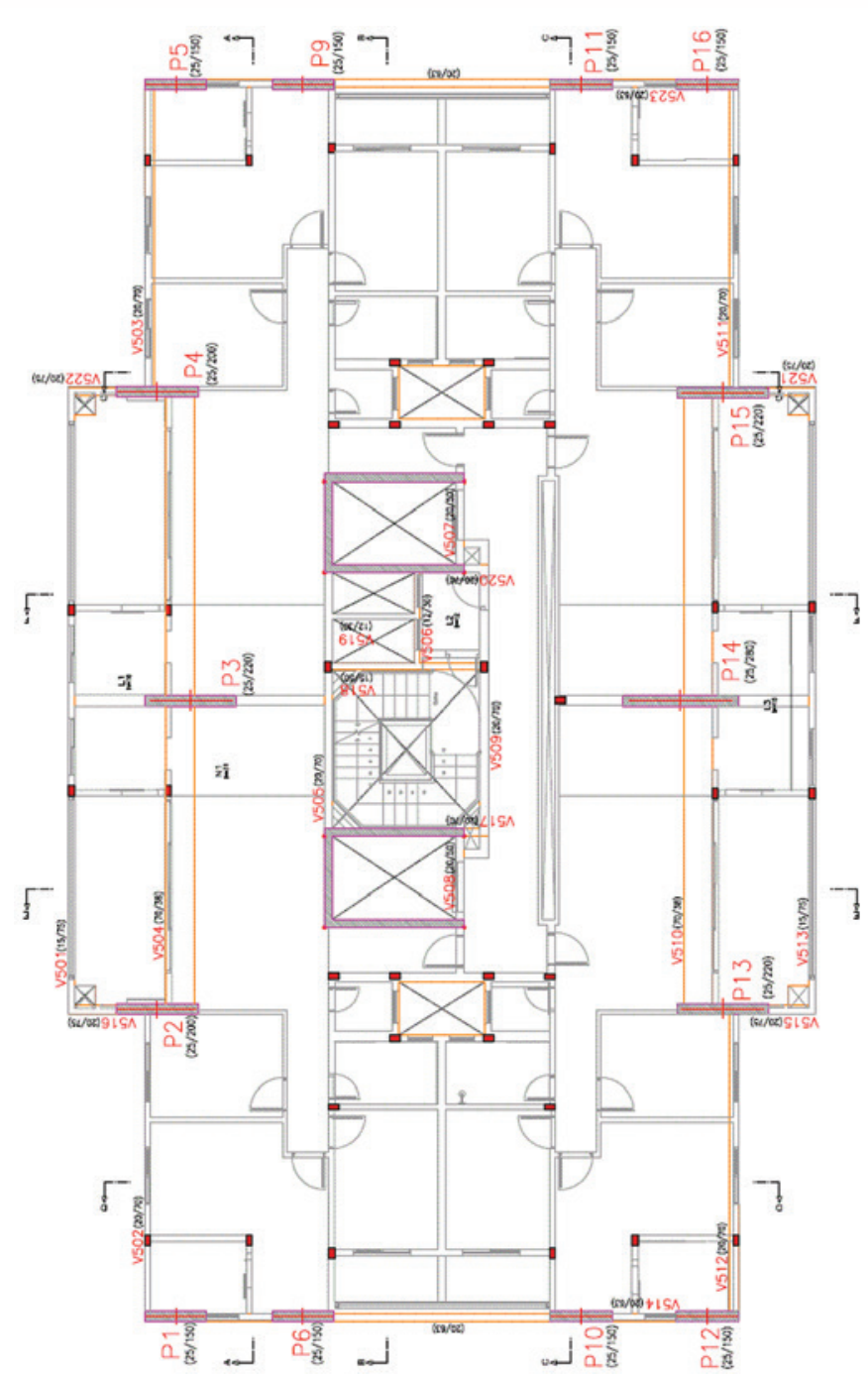

Figure 1

Standard floor of building

The standard floor of the building is shown in Figure 1, totaling an area of $8,741.19 \mathrm{~m}^{2}$. For the implementation of the structure, stress and displacement analyses and the determination of the reinforcement, the CAD/TQS 18 computational system was used.

The structural design was carried out without considering the stairs and the foundations, since these elements would not be subject to optimizations and would not directly influence the overall stability of the structure.

\subsubsection{Model characteristics}

For the structural analysis, Model IV available in the CAD/TQS system was used. This model consists of beams and columns composing the space gantry, with the rigid diaphragm effect of the slabs properly incorporated. In this model, the effects of horizontal and vertical actions on the beams and columns are calculated as space frames. In turn, the slabs interact with the space frames by transferring the stresses though the bars that

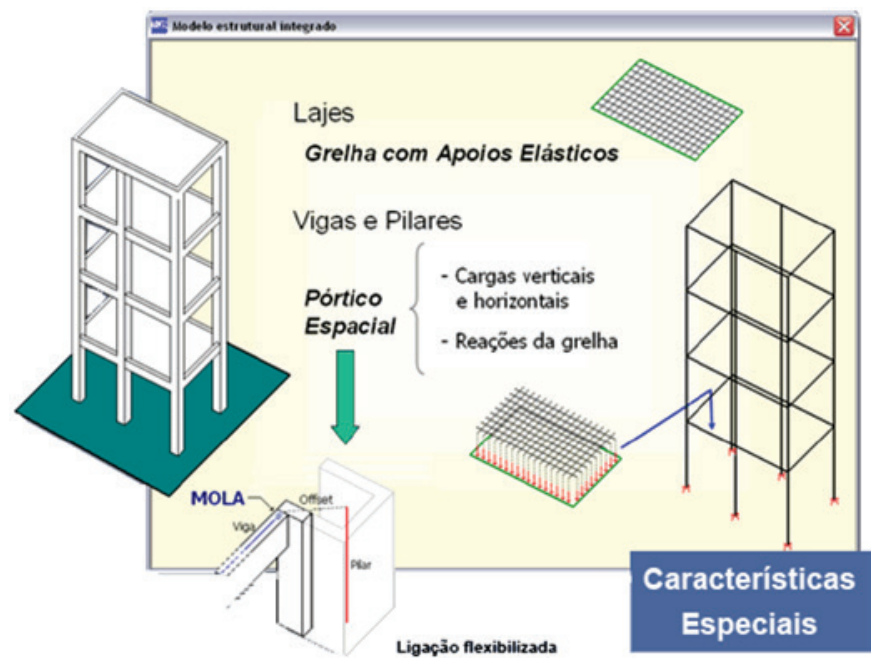

Figure 2

Structural Model IV (TQS Informática Ltda.)

make up the slab's discretization grid as concentrated loads on the beams, making this distribution of stresses quite realistic, as shown in Figure 2.

The ULS model used to obtain the stresses necessary for the design and detailing of the structural elements considered approximate physical non-linearity coefficients, as indicated in item 15.7.3 of ABNT NBR 6118: 2014 [7].

- slabs: $(\mathrm{EI})_{\mathrm{sec}}=0,3 \mathrm{E}_{\mathrm{ci}} \mathrm{I}_{\mathrm{c}}$

beams: $(\mathrm{EI})_{\mathrm{sec}}=0,4 \mathrm{E}_{\mathrm{cic}} \mathrm{I}$

columns: $(\mathrm{EI})_{\mathrm{sec}}=0,8 \mathrm{E}_{\mathrm{cic}}$

\subsubsection{Actions}

\subsubsection{WIND}

For the calculation of the wind acting on the structure, the data below was considered, and this is summarized in Table 1.

- $\mathrm{V}_{\mathrm{o}}=45 \mathrm{~m} / \mathrm{s}$;

- $S_{1}=1.00$, since the building was designed on a flat or slightly uneven terrain;

- $S_{2}=1.02$, since the building falls in class $C$ of dimensions (constructions exceeding 50 meters) and category IV of terrain roughness (terrains covered by numerous and sparsely spaced obstacles in a forest, industrial or urbanized area, with an average top level of 10 meters);

- $S_{3}=1.00$, since it is a residential building.

For the calculation of the drag coefficients, the indices $I_{1} / I_{2}$ and $h / l_{1}$ were calculated. For winds in $0^{\circ} / 180^{\circ}$ directions:

\section{Table 1}

Data used to calculate wind actions

\begin{tabular}{cccc}
\hline \multicolumn{4}{c}{ Measurement of wind actions } \\
\hline $\begin{array}{c}\text { Basic speed } \\
(\mathrm{m} / \mathrm{s})\end{array}$ & s1 & S2 & S3 \\
\hline 45.00 & 1.00 & 1.02 & 1.00 \\
\hline
\end{tabular}


Table 2

Heights' floor

\begin{tabular}{cc}
\hline Floor & Height $(\mathrm{m})$ \\
\hline Water tank & 3.98 \\
Below the water tank & 3.57 \\
Floor type (16x) & 3.15 \\
Ground floor & 3.80 \\
\hline
\end{tabular}

$\mathrm{h} / \mathrm{l}_{1}=3,43 ;$

$\mathrm{I}_{1} / \mathrm{I}_{2}=0,60$.

With the indices and the abacus in ABNT NBR 6123: 1988 [12], the drag coefficient $\mathrm{Ca}=1.10$ was determined.

For winds in $90^{\circ} / 270^{\circ}$ directions:

$\mathrm{h} / \mathrm{I}_{1}=2,06$;

- $\mathrm{I}_{1} / \mathrm{I}_{2}=1,67$.

With the indices and the abacus in ABNT NBR 6123: 1988 [12], the drag coefficient $\mathrm{Ca}=1.32$ was determined.

\subsubsection{ACTIONS ON SLABS}

The program used presents a database of loads previously registered. In this way, a load denominated "APART1", representing $1.00 \mathrm{kN} / \mathrm{m}^{2}\left(0.10 \mathrm{tf} / \mathrm{m}^{2}\right)$ of live or permanent load and $1.50 \mathrm{kN} / \mathrm{m}^{2}$ $\left(0.15 \mathrm{tf} / \mathrm{m}^{2}\right)$ of accidental load were used for the slabs (both solid and ribbed), in addition to the weight of the slabs.

\subsubsection{ACTIONS ON BEAMS}

For the beams, linearly distributed loads were applied - representing the masonry fence, called "TJVAZ15", and consisting of 1.80 $\mathrm{kN} / \mathrm{m}^{2}\left(0.18 \mathrm{tf} / \mathrm{m}^{2}\right)$ of live or permanent load, varying according to the slabs since they present different depths, as shown in Table 2, besides their weight.

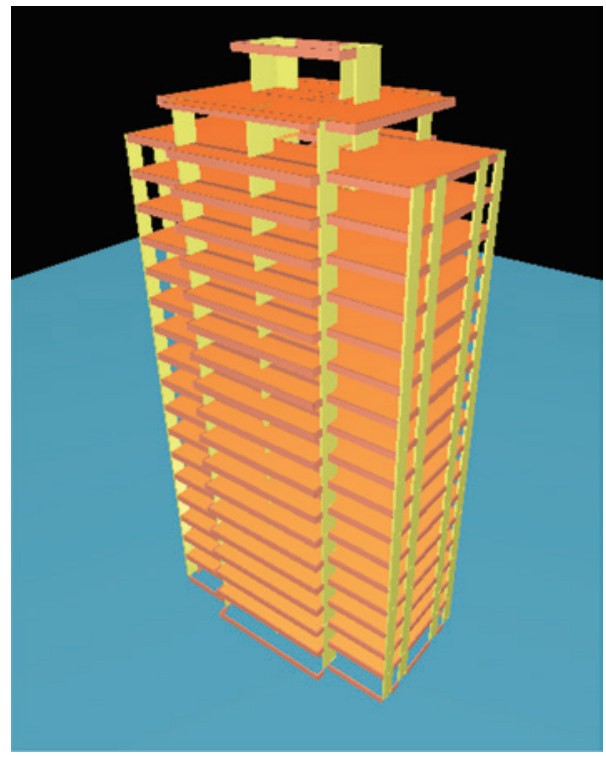

\section{Figure 3}

Three-dimensional view of the building

\subsection{Preliminary sizing}

After the positioning of the columns, beams and slabs in the building, according to Figure 3, the dimensioning of the beams, slabs and rigid core was carried out for a concrete of $35 \mathrm{MPa}$ characteristic compression strength $\left(f_{c k}\right)$. Thus, these structural elements had their dimensions fixed in order to proceed to a detailed study of the columns.

The floors of the building are composed of solid and ribbed trapezoidal section slabs, the latter being used in most of the structure, as shown in Figure 4.

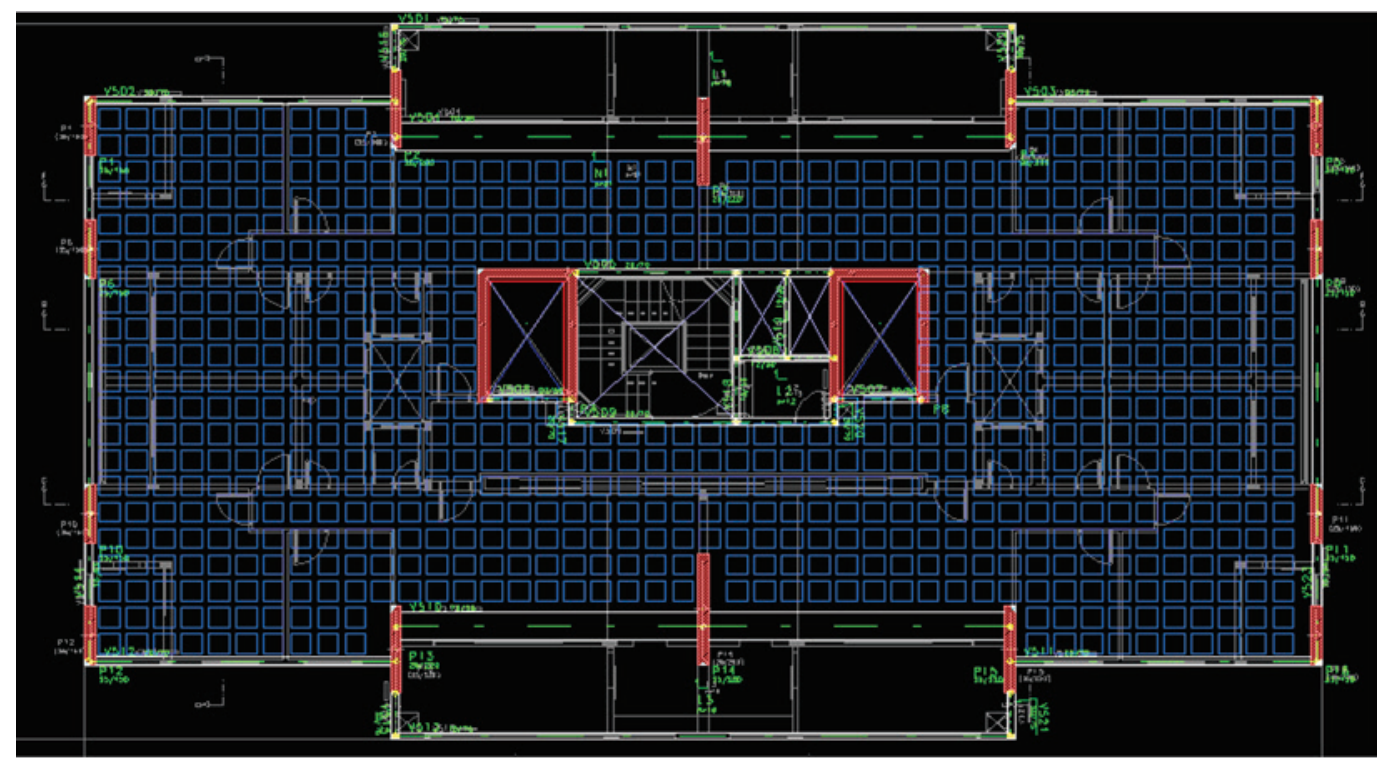

Figure 4

Standard floor with positioning of columns, rigid core, edge beams and ribbed and solid slabs 


\subsection{Column section optimization}

In this stage of the study, after defining the dimensions of the beams, slabs, and rigid core, the effects of the applied loads were analyzed in the ground floor columns, since these columns support the highest loads in the building. It is worth mentioning that all the columns contained in the structure are submitted to oblique bending.

Thus, these columns were studied individually using the CAD/Pillar tool of the CAD/TQS system, seeking to optimize the columns' cross-sections as the concrete compressive strength varied. The aim was to vary the $f_{c k}$ of the columns in increments of $5 \mathrm{MPa}$, starting at $35 \mathrm{MPa}$ and going up to $90 \mathrm{MPa}$.

For each $f_{c k}$, the cross-sections of the columns were optimized, fixing the widths by $25 \mathrm{~cm}$ and reducing the heights in an iterative manner, aiming to keep the section resistance close to the generated effects by means of the column's envelope of resistant moments and trying to meet the regulatory restrictions regarding the horizontal displacement of the building.

The iterative method consisted of reducing the heights in increments of $5 \mathrm{~cm}$ and performing a global processing of the structure at each reduction, until the CAD/TQS program displayed an error message warning that it was not possible to dimension this element. At this stage of the analysis, the normative restrictions regarding the horizontal displacement of the building were verified. Therefore, the final height of each column is the height of the last iteration before the program indicated that no further dimensioning was possible.

The envelope of resistant moments determines the sizing limit of a column, given that the load demands - both in the base (represented by the letter $B$ ) and in the top (represented by the letter T) - must be included in the envelope, otherwise the structural element will fail.

Some columns may also have their dimensioning limited by the envelope of minimum moments, according to ABNT NBR 6118: 2014 [7]. In the program, this envelope is delimited by an ellipse, as shown in Figure 5. In this manner, the dimensioning of the

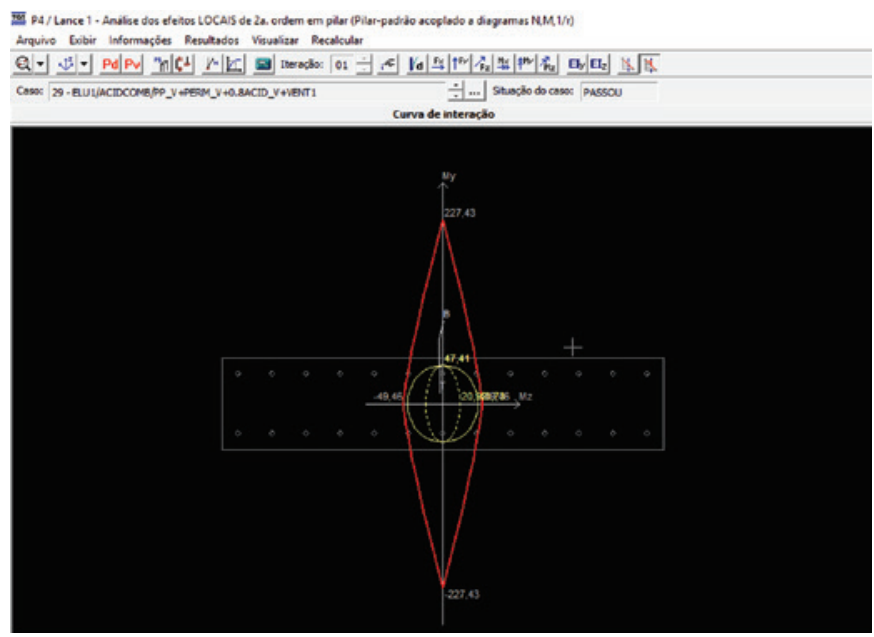

\section{Figure 5}

Envelope of moments of resistance and minimum moments column will only be possible if the envelope of minimum moments is contained within the envelope of resistant moments.

It should be noted that the columns that have been modified have a constant cross-section along their height, in order to simplify the interpretation and analysis of the results. The initial dimensions of the columns, according to the structural design used, are shown in Table 3.

The columns P7 and P8 are the rigid cores and, as they have been maintained with constant cross-sections, are not contained in Table 3. It was decided to fix the dimensions of the rigid cores since they constitute bracing elements with the function of delimiting the elevator shafts, and little could done to modify these elements with respect to their cross-sections, since this would directly influence the architecture of the building. Therefore, keeping the dimensions of these elements fixed, the results obtained and the analyses correspond to the columns only.

From the columns shown in Table 3, only P2, P3, P4, P13, P14, and $\mathrm{P} 15$ start on the ground floor and terminate below the water tank, with the others terminating on the top floor.

It is worth noting that the columns' dimensions shown in Table 3, as well as the initial strength of all the structural elements, $f_{c k}=35 \mathrm{MPa}$, were defined by the designer who developed the original design. Thus, the optimization of the columns' cross-sections was first carried out for $f_{c k}=35 \mathrm{MPa}$, and subsequently for other strengths. Given that the focus of this study is the optimization of structural elements, more specifically of columns, an optimized $f_{c k}$ of $35 \mathrm{MPa}$ was defined as the benchmark to compare the results of the other strengths, otherwise this strength would not be subjected to optimization, compromising the interpretation of the results obtained.

\section{Results and discussions}

As mentioned in Section 2, all the structural elements of the building were first dimensioned with $f_{c k}=35 \mathrm{MPa}$, since this characteristic compressive strength was fixed for the beams, slabs and rigid cores, whilst for the columns, this strength varied in increments of $5 \mathrm{MPa}$ until reaching the established maximum of $90 \mathrm{MPa}$. The

\section{Table 3}

Columns' dimensions

\begin{tabular}{ccc}
\hline Column & Fixed width $(\mathrm{cm})$ & Height $(\mathrm{cm})$ \\
\hline P1 & 25.00 & 150.00 \\
P2 & 25.00 & 200.00 \\
P3 & 25.00 & 220.00 \\
P4 & 25.00 & 200.00 \\
P5 & 25.00 & 150.00 \\
P6 & 25.00 & 150.00 \\
P9 & 25.00 & 150.00 \\
P10 & 25.00 & 150.00 \\
P11 & 25.00 & 150.00 \\
P12 & 25.00 & 150.00 \\
P13 & 25.00 & 220.00 \\
P14 & 25.00 & 280.00 \\
P15 & 25.00 & 220.00 \\
P16 & 25.00 & 150.00 \\
\hline
\end{tabular}


Table 4

Minimum heights of columns' cross-sections

\begin{tabular}{|c|c|c|c|c|c|c|c|c|c|c|c|c|c|c|}
\hline $\begin{array}{c}f_{\mathrm{ck}} \\
(\mathrm{MPa})\end{array}$ & P1 & P2 & P3 & P4 & P5 & P6 & P9 & P10 & P11 & P12 & P13 & P14 & P15 & P16 \\
\hline 35 & 1.50 & 2.00 & 2.20 & 2.00 & 1.50 & 1.50 & 1.50 & 1.50 & 1.50 & 1.50 & 2.20 & 2.80 & 2.20 & 1.50 \\
\hline 35 - Ot & 1.35 & 1.65 & 1.40 & 1.65 & 1.50 & 0.85 & 0.85 & 0.60 & 0.60 & 1.30 & 1.75 & 1.65 & 1.95 & 1.50 \\
\hline 40 & 1.20 & 1.60 & 1.35 & 1.65 & 1.40 & 0.60 & 0.80 & 0.60 & 0.60 & 1.30 & 1.65 & 1.50 & 1.75 & 1.50 \\
\hline 45 & 1.05 & 1.55 & 1.35 & 1.60 & 1.20 & 0.60 & 0.60 & 0.60 & 0.60 & 1.30 & 1.65 & 1.40 & 1.70 & 1.45 \\
\hline 50 & 0.90 & 1.55 & 1.30 & 1.55 & 1.05 & 0.60 & 0.60 & 0.60 & 0.60 & 1.30 & 1.65 & 1.40 & 1.65 & 1.25 \\
\hline 55 & 0.80 & 1.50 & 1.30 & 1.55 & 0.95 & 0.60 & 0.60 & 0.60 & 0.60 & 1.20 & 1.55 & 1.40 & 1.65 & 1.15 \\
\hline 60 & 0.70 & 1.45 & 1.30 & 1.45 & 0.85 & 0.60 & 0.60 & 0.60 & 0.60 & 0.95 & 1.55 & 1.35 & 1.55 & 1.05 \\
\hline 65 & 0.70 & 1.35 & 1.30 & 1.40 & 0.80 & 0.60 & 0.60 & 0.60 & 0.60 & 0.95 & 1.55 & 1.30 & 1.55 & 0.95 \\
\hline 70 & 0.65 & 1.30 & 1.30 & 1.35 & 0.75 & 0.60 & 0.60 & 0.60 & 0.60 & 0.95 & 1.50 & 1.30 & 1.55 & 0.90 \\
\hline 75 & 0.65 & 1.30 & 1.30 & 1.35 & 0.70 & 0.60 & 0.60 & 0.60 & 0.60 & 0.85 & 1.45 & 1.30 & 1.55 & 0.85 \\
\hline 80 & 0.60 & 1.30 & 1.30 & 1.30 & 0.65 & 0.60 & 0.60 & 0.60 & 0.60 & 0.80 & 1.40 & 1.30 & 1.55 & 0.80 \\
\hline 85 & 0.60 & 1.30 & 1.20 & 1.20 & 0.60 & 0.60 & 0.60 & 0.60 & 0.60 & 0.75 & 1.35 & 1.30 & 1.45 & 0.75 \\
\hline 90 & 0.60 & 1.20 & 1.15 & 1.20 & 0.60 & 0.60 & 0.60 & 0.60 & 0.60 & 0.70 & 1.35 & 1.30 & 1.45 & 0.65 \\
\hline
\end{tabular}

cross-sectional width of the columns was set at $25 \mathrm{~cm}$, while the height was iteratively reduced. The objective was to find the optimized section of each column, that is, the smallest possible height for the analyzed $f_{c k}$. The structure underwent global processing at each iteration and subsequently, the parameters of global stability and displacement at the top of the building and between floors were analyzed. An individualized analysis of local second-order effects by the standard column method coupled with diagrams $N, M$, $1 / r$ was also performed using the CAD/ Pillar tool.

\subsection{Optimized sections}

Considering the load combinations and due demands for each column, as well as its envelope of resistant moments, and analyzing the structural behavior of the building through the parameters of global stability and horizontal displacement of the top of the building and between floors, it is possible to determine the minimum (cross-section) height of each column. It should be noted that the base of the columns was fixed at $25 \mathrm{~cm}$, since according to ABNT NBR 6118: 2014 [7], the minimum dimension for columns and wall columns is $19 \mathrm{~cm}$, although dimensions between $19 \mathrm{~cm}$ and $14 \mathrm{~cm}$ are allowed in special cases, therefore, the reduction would be negligible. Table 4 describes the minimum height of each column for each $f_{c k}$ analyzed. Recalling what has been said previously, columns P7 and P8 are the rigid cores and belong to the group of structural elements that had their dimensions fixed, together with the beams and slabs (solid and ribbed). The graph in Figure 6 illustrates the variation of the columns' cross-sectional heights shown in Table 4.

In order to demonstrate how significant the reduction was, a study of the total area of the columns for each $f_{c k}$ was carried out and

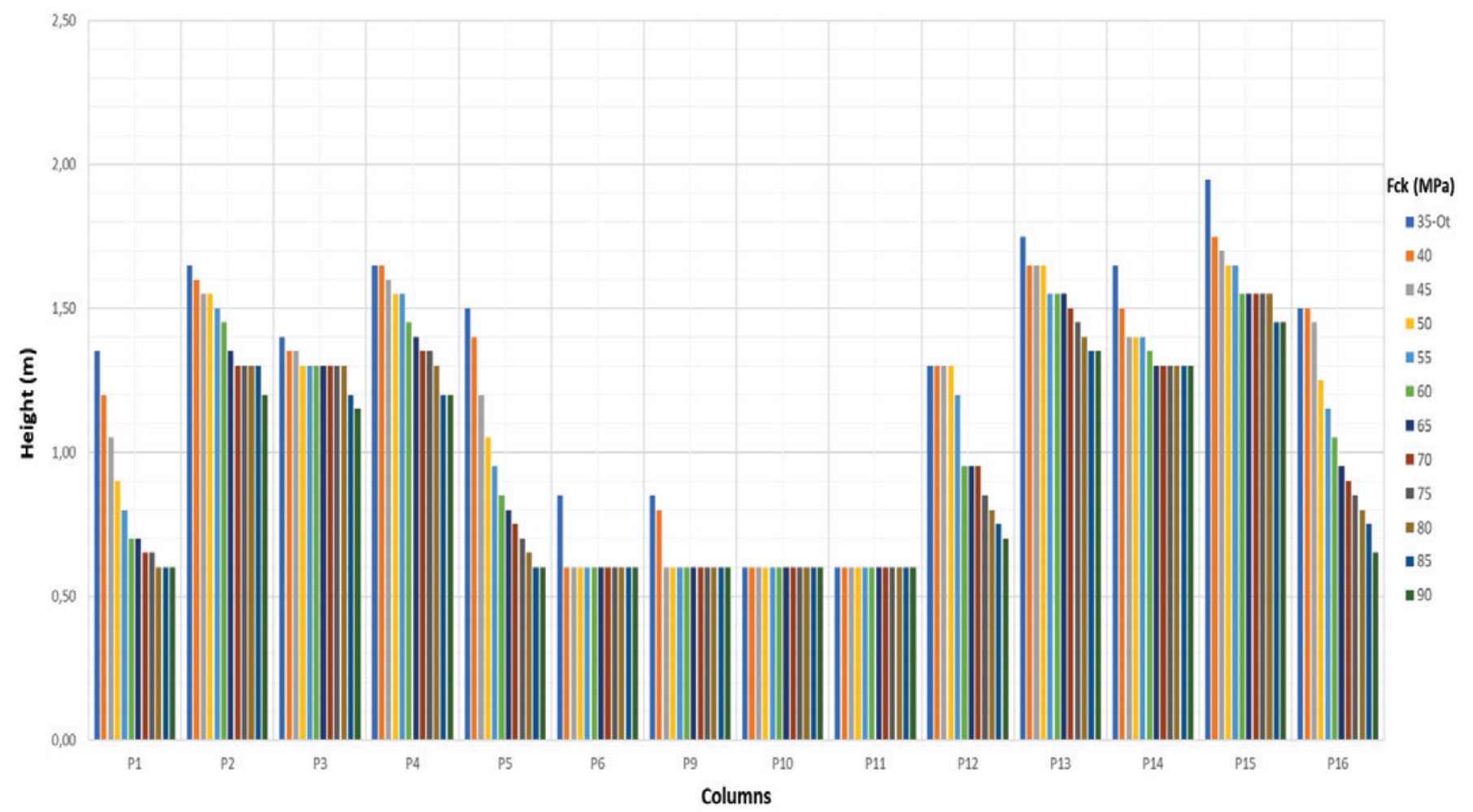

Figure 6

Height variations of the columns' cross-sections 


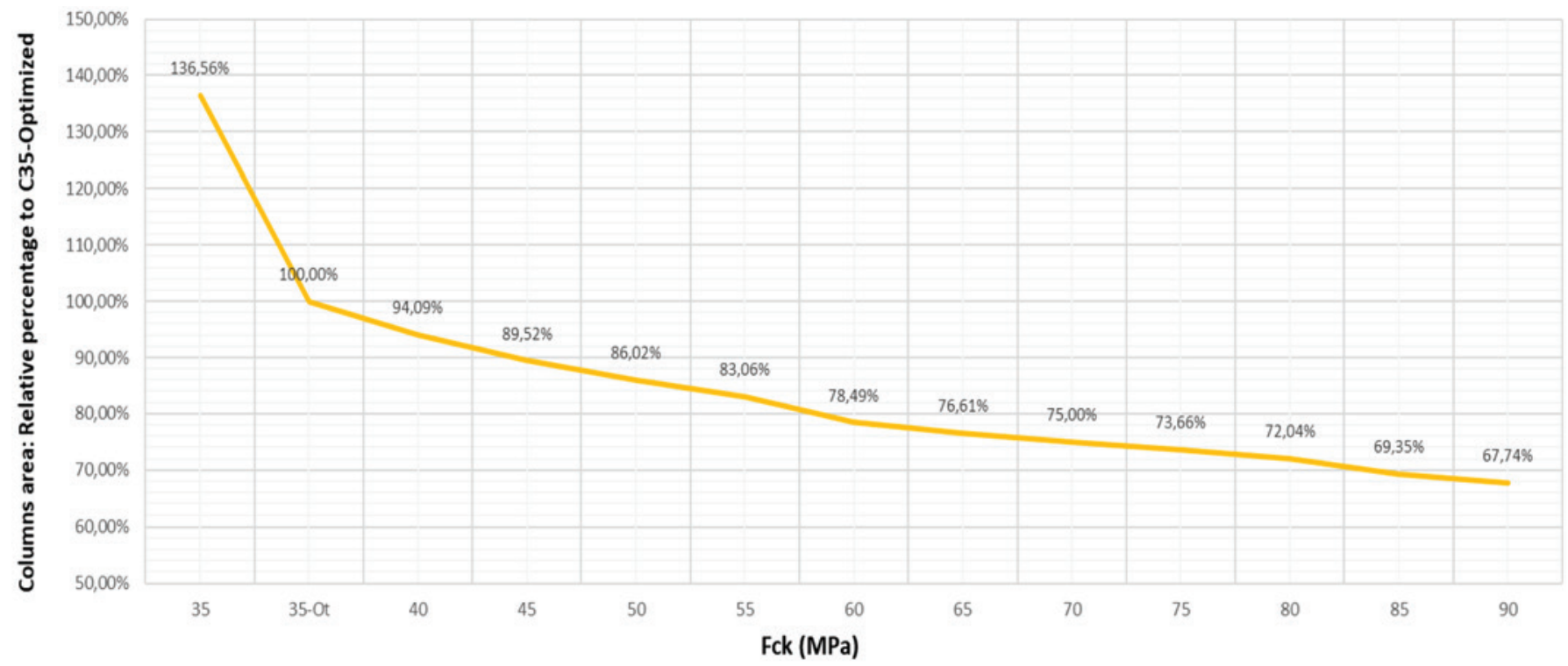

\section{Figure 7}

Variation of the total area of the columns

shown in Figure 7. Through the graph in Figure 7, the gradual reduction of the columns' total area can be observed, reaching a reduction of $32.26 \%$ of total area when comparing the C90 and optimized C35 cases.

\subsection{Horizontal displacement}

As the columns are reduced in area, the building changes its structural behavior, becoming more susceptible to horizontal displacements. In view of this, the horizontal displacements at the top and between the floors of the building were analyzed by considering Item 13.3 - Displacement limits specified by ABNT NBR 6118: 2014 [7], which sets the limit of $H / 1700$ for the top of the building and $H / 850$ between floors (where $H$ is the total height of the build- ing and $H_{i}$ is the height between floors). Therefore, for the building in question, $H=61.75 \mathrm{~m}$ and $H_{i}=3.15 \mathrm{~m}$ (considering the lowest height between floors, as it will result in less displacement), and the limits are:

$H / 1700=3.63 \mathrm{~cm}$ and $H / 850=0.37 \mathrm{~cm}$.

These displacement limits were the ones considered for the structural optimization, aiming at the safety of the building as a whole. It is worth mentioning that, for the C90 columns, the limit of the section optimization was the horizontal displacement at the top of the building, with a maximum value of $3.63 \mathrm{~cm}$, as shown in Table 5 . The variation of the horizontal displacements is shown in Table 5 and Figure 8.

It can be observed that the horizontal displacements, both at the top of the building and between floors, tend to increase as the com-

\section{Table 5}

Minimum heights of columns' cross-sections

\begin{tabular}{ccccc}
\hline$f_{c k}$ & \multicolumn{2}{c}{ Horizontal deformation $(\mathbf{c m})$} & \multicolumn{2}{c}{ Relative percentage to C35 - Ot } \\
\cline { 2 - 5 }$(\mathbf{M P a})$ & On top & Between floors & On top & Between floors \\
\hline 35 & 2.10 & 0.13 & $67.31 \%$ & $68.42 \%$ \\
$35-$-Ot & 3.12 & 0.19 & $100.00 \%$ & $100.00 \%$ \\
40 & 3.34 & 0.21 & $107.05 \%$ & $110.53 \%$ \\
45 & 3.39 & 0.21 & $108.65 \%$ & $110.53 \%$ \\
50 & 3.38 & 0.21 & $108.33 \%$ & $110.53 \%$ \\
55 & 3.42 & 0.21 & $109.62 \%$ & $110.53 \%$ \\
60 & 3.51 & 0.21 & $112.50 \%$ & $110.53 \%$ \\
65 & 3.51 & 0.21 & $112.50 \%$ & $110.53 \%$ \\
70 & 3.51 & 0.21 & $112.50 \%$ & $110.53 \%$ \\
75 & 3.52 & 0.21 & $112.82 \%$ & $110.53 \%$ \\
80 & 3.55 & 0.22 & $113.78 \%$ & $115.79 \%$ \\
95 & 3.59 & 0.22 & $116.06 \%$ & $115.79 \%$ \\
90 & 3.63 & 0.22 & $115.79 \%$ \\
\hline
\end{tabular}




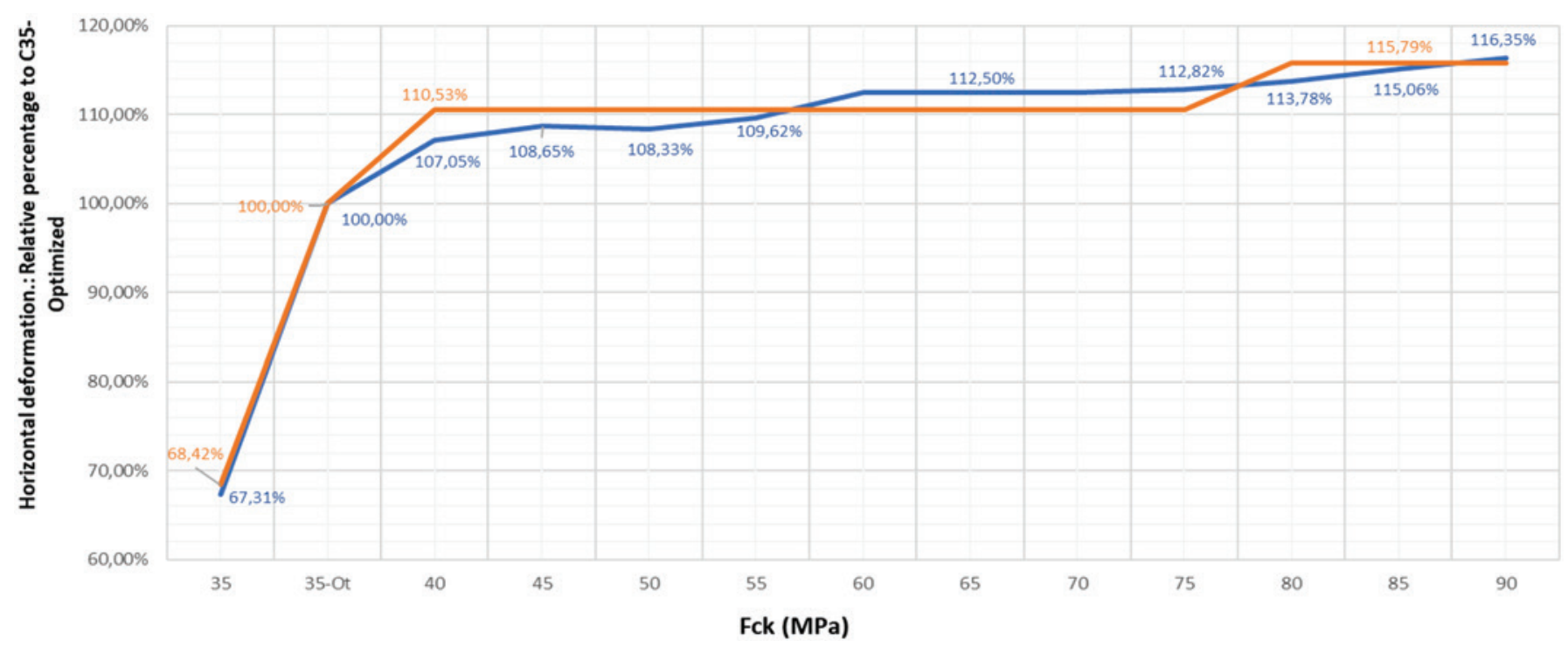

\section{Figure 8}

Variation of horizontal displacements

pressive strength increases due to the reduced area of the columns. Comparing the values obtained for the optimized C35 and C90 cases, increases in horizontal displacements of more than $15 \%$ are obtained.

\subsection{Global stability parameters}

The CAD/TQS program verifies the overall stability of the structure through the conventional parameters $\alpha$ and $\gamma_{z}$.

$\alpha=H_{\text {tot }} \cdot \sqrt{\frac{N_{k}}{\left(E_{c s} I_{c}\right)}}$

$\gamma_{z}=\frac{1}{1-\frac{\Delta M_{t o t, d}}{M_{t o t, d}}}$

Thus, an analysis of global stability parameters was performed to analyze global second-order effects.

According to Equation 2, which describes the calculation of $\gamma_{z}$, it can be noted that the factor $M_{1, t o t, d}$ is constant, since this represents the sum of the moments of all the horizontal forces (in the case of this study, only the wind forces are present) relative to the base of the structure. Therefore, the only variable value

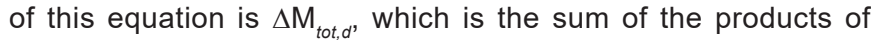
all vertical forces acting on the structure due to the horizontal displacements of their respective points of application, obtained in the first-order analysis. Subsequently, with the optimization of the columns, their weights decreased, reducing the vertical forces acting on the structure and consequently the secondorder moments, causing the parameters $\gamma_{z}$ to become smaller, as shown in Figure 9. The same happens with the coefficient $\alpha$, since it is influenced by the columns' weight and the reduction of stiffness.

The reduction of the values of the stability parameters $\gamma_{z}$ and $\alpha$, presented in Figure 9, draws attention, since the horizontal displacements of the building have increased with the column optimization process. To demonstrate the behavior of the global
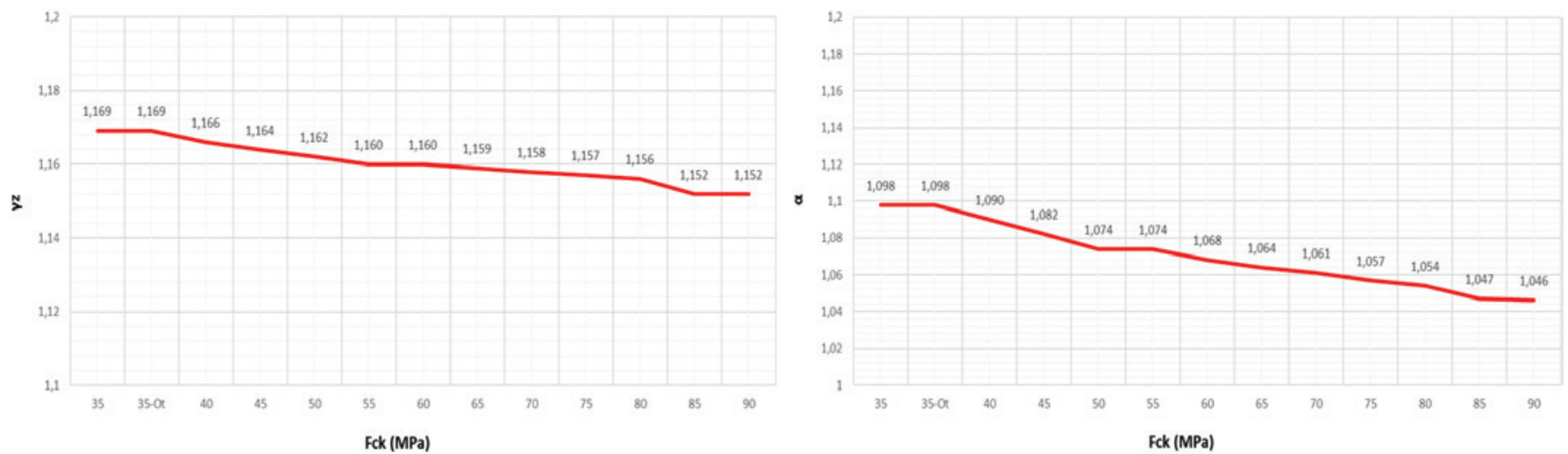

Figure 9

Variation of the $\gamma_{z}$ parameter and the $\alpha$ coefficient in relation to $f_{c k}$ 
Table 6

Example calculation of parameters $\gamma_{z}$ and $\alpha$

\begin{tabular}{cc}
\hline Columns $-\mathrm{f}_{\mathrm{ck}}=35 \mathrm{MPa}$ & Columns $-\mathrm{f}_{\mathrm{ck}}=90 \mathrm{MPa}$ \\
\hline$\gamma_{z}=\frac{1}{1-\frac{\Delta M_{t o t, d}}{M_{1, t o t, d}}}=\frac{1}{1-\frac{550,66}{3809}}=1,169$ & $\gamma_{z}=\frac{1}{1-\frac{\Delta M_{t o t, d}}{M_{1, t o t, d}}}=\frac{1}{1-\frac{502,58}{3809}}=1,152$ \\
$\propto=H_{t o t} \sqrt{\frac{N_{k}}{\left(E_{c s} I_{c}\right)}}=61,75 \sqrt{\frac{294,5}{(931351,15)}}=1,098$ & $\alpha=H_{t o t} \sqrt{\frac{N_{k}}{\left(E_{c s} I_{c}\right)}}=61,75 \sqrt{\frac{212,5}{(740862,30)}}=1,046$
\end{tabular}

Table 7

Unit costs of concrete

\begin{tabular}{ccc}
\hline \multicolumn{3}{c}{ Unit costs } \\
\hline $\begin{array}{c}\mathbf{f}_{\mathbf{c}_{\mathrm{c}}} \\
(\mathbf{M P a})\end{array}$ & $\mathbf{R} \mathbf{/} \mathbf{m}^{\mathbf{3}}$ & Reference \\
\hline 35 & 302.44 & CPOS \\
40 & 352.40 & CPOS \\
45 & 375.00 & Budgets \\
50 & 387.70 & SINAPI \\
55 & 450.00 & Budgets \\
60 & 497.85 & SINAPI \\
65 & 535.00 & Budgets \\
70 & 590.00 & Budgets \\
75 & 640.00 & Budgets \\
80 & 687.30 & SINAPI \\
85 & 715.00 & Budgets \\
90 & 750.00 & Budgets \\
\hline
\end{tabular}

\section{Table 8}

Unit costs of steel

\begin{tabular}{cc}
\hline \multicolumn{3}{c}{ Unit costs } \\
\hline$\Phi(\mathbf{m m})$ & $\mathbf{R} \mathbf{/ k g}$ \\
\hline 4.2 & 5.70 \\
5.0 & 5.15 \\
6.3 & 7.21 \\
8.0 & 7.14 \\
10.0 & 5.82 \\
12.5 & 4.73 \\
16.0 & 3.45 \\
20.0 & 3.18 \\
25.0 & 3.58 \\
\hline
\end{tabular}

stability parameters, the calculation of $\gamma_{z}$ and $\alpha$ for $f_{c k}$ values between $35 \mathrm{MPa}$ and $90 \mathrm{MPa}$ was taken as an example, as shown in Table 6. It can be observed in Table 6 that for the calculation of $\gamma_{z}$ the increase in horizontal displacements with a reduction of the columns' crosssections was not sufficient to promote an increase in the value of $\Delta \mathrm{M}_{\text {tot, }, \mathrm{r}}$, but actually a reduction of this value occurred, which confirms that the reduction of vertical forces was predominant for the reduction of the $\gamma_{z}$ parameter. Similarly, for the calculation of $\alpha$, the decrease in stiffness $\left(E_{c s} I_{c}\right)$ with the reduction of the columns sections did not predominate on the reduction of vertical forces $\left(N_{k}\right)$, confirming that the reduction of vertical forces was predominant for the reduction of $\alpha$. Therefore, the variation of parameter $\gamma_{z}$ was less than $2 \%$ between the maximum and minimum resistances considered in this study; likewise, the variation of the $\alpha$ coefficient was less than $5 \%$, as shown in the graphs in Figure 9.

\subsection{Quantities and costs}

In this analysis, the total quantities and costs of concrete, steel and formwork were calculated to determine the variation of the material costs of the structure, since the purpose of this study is to vary only the characteristic compression strength $\left(f_{c k}\right)$ of the columns, associated to the optimization of their cross-sections.

For this analysis, reference cost sheets were used, such as the Table of the National System of Costs Survey and Indices of the Civil Construction (SINAPI) (Compositions - January 2017) and the bulletin of cost references from Companhia Paulista de Obras e Serviços (CPOS), in addition to market quotations.

The unit costs of concrete volumes (Table 7), were obtained through SINAPI, the CPOS bulletin and market quotations. In turn, unit costs of steel for the different diameters (Table 8 ) were obtained only from the SINAPI Table. The unit cost of wood planks, also extracted from the SINAPI Table, was $\mathrm{R} \$ 72.19 / \mathrm{m}^{2}$.

\section{Table 9}

Total costs

\begin{tabular}{|c|c|c|c|c|c|}
\hline $\begin{array}{c}f_{\mathrm{ck}} \\
(\mathrm{MPa})\end{array}$ & Concrete & Steel & Formworks & Total & $\begin{array}{c}\text { Relative reduction } \\
\text { to } \mathrm{C} 35-\mathrm{Ot}\end{array}$ \\
\hline 35 & R\$ 751,563.40 & $\mathrm{R} \$ 1,176,605.33$ & R\$ 713,619.81 & $R \$ 2,641,788.54$ & $100.28 \%$ \\
\hline 35 - Ot & $R \$ 726,339.90$ & $\mathrm{R} \$ 1,241,050.71$ & $\mathrm{R} \$ 666,934.53$ & $R \$ 2,634,325.15$ & $100.00 \%$ \\
\hline 40 & $\mathrm{R} \$ 734,649.12$ & $R \$ 1,203,952.42$ & $\mathrm{R} \$ 659,628.91$ & $R \$ 2,598,230.44$ & $98.63 \%$ \\
\hline 45 & $R \$ 736,289.28$ & $R \$ 1,199,036.95$ & $R \$ 654,077.50$ & $R \$ 2,589,403.72$ & $98.29 \%$ \\
\hline 50 & $\mathrm{R} \$ 736,261.92$ & $R \$ 1,173,733.18$ & $R \$ 649,883.26$ & $R \$ 2,559,878.36$ & $97.17 \%$ \\
\hline 55 & $\mathrm{R} \$ 747,247.61$ & $\mathrm{R} \$ 1,232,150.18$ & $\mathrm{R} \$ 646,432.57$ & $R \$ 2,625,830.36$ & $99.68 \%$ \\
\hline 60 & $R \$ 752,376.62$ & $\mathrm{R} \$ 1,223,884.80$ & $\mathrm{R} \$ 640,996.67$ & $R \$ 2.617 .258 .09$ & $99.35 \%$ \\
\hline 65 & $\mathrm{R} \$ 757,632.14$ & $R \$ 1,218,920.70$ & $\mathrm{R} \$ 638,701.03$ & $R \$ 2,615,253.86$ & $99.28 \%$ \\
\hline 70 & R\$ 766,399.95 & $R \$ 1,220,299.07$ & $R \$ 636,816.87$ & $R \$ 2,623,515.88$ & $99.59 \%$ \\
\hline 75 & $\mathrm{R} \$ 774,226.41$ & $R \$ 1,216,568.47$ & $\mathrm{R} \$ 635,250.34$ & $R \$ 2,626,045.22$ & $99.69 \%$ \\
\hline 80 & $\mathrm{R} \$ 780,711.55$ & $R \$ 1,212,730.96$ & $\mathrm{R} \$ 633,366.18$ & $R \$ 2,626,808.69$ & $99.71 \%$ \\
\hline 85 & $\mathrm{R} \$ 781,228.29$ & $\mathrm{R} \$ 1,206,299.87$ & $\mathrm{R} \$ 630,225.92$ & $R \$ 2,617,754.08$ & $99.37 \%$ \\
\hline 90 & $\mathrm{R} \$ 784,650.20$ & $\mathrm{R} \$ 1,199,537.40$ & $\mathrm{R} \$ 628,240.69$ & $R \$ 2,612,428.29$ & $99.17 \%$ \\
\hline
\end{tabular}




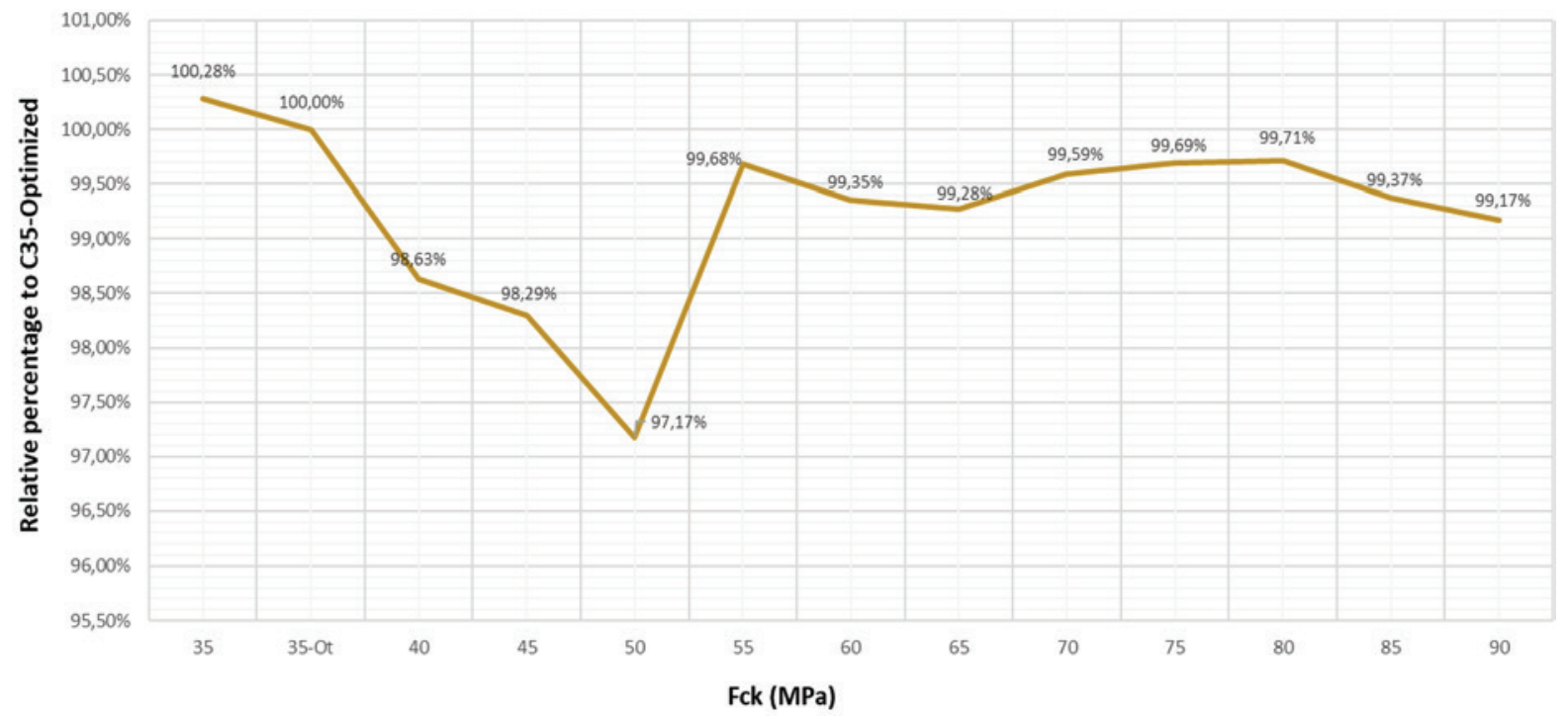

\section{Figure 10}

Variation of the costs of the structure in relation to the materials

Based on the costs of each of the materials cited, an analysis of the structural costs related to the materials was performed in order to evaluate the financial impact caused by the optimization of the columns. Table 9 and Figure 10 illustrate these results.

Reductions in the total costs were observed with respect to $f_{c k}=$ $35 \mathrm{MPa}$ and optimized for strength higher than this, reaching just under $3 \%$ for $f_{c k}=50 \mathrm{MPa}$ and a total average of approximately $1 \%$ for the other resistances.

These results demonstrate that, although the unit costs of HSC are considerably higher (Table 7), when analyzed together with the costs of steel and wood (formwork), this cost increase is offset by a reduction in concrete volume and other materials.

\section{Conclusions}

With the application of more resistant concrete in columns and by taking advantage of this property in the sizing of the structure, it was possible to obtain considerable reductions in the total areas of the columns as the characteristic compression strength concrete was increased. A reduction of $32.26 \%$ was achieved when comparing between the optimized C90 and C35 case. This fact is of great relevance, since it reflects in a better use of the building area and results in, for example, extra parking spaces and useful areas.

The analysis of the material costs of the structure showed that it is possible to reduce costs by approximately $3 \%$ with a concrete of $f_{c k}$ $=50 \mathrm{MPa}$ and a total average of approximately $1 \%$ for the other resistances; in other words, the savings generated by the reduction in concrete volume and other materials offset the higher costs of HSC. The design of the building for all the strength classes was compliant with the safety requirements, in accordance with ABNT NBR 6118: 2014 [7]. It should be noted that the limiting factor for the design of the building for the C90 case was the horizontal displacement, which reached a value of $H / 1700$ (in this case $3.63 \mathrm{~cm}$ ) recommended in the standard.

Regarding the global stability parameters, a reduction in the order of $5 \%$ was observed for the $\alpha$ coefficient and $2 \%$ for parameter $\gamma_{z}$. This reduction can be justified, given that with the columns' optimization, a reduction of their weight also occurs, leading to a reduction of the vertical forces acting on the structure and consequently of second-order moments.

Regarding the execution, when beams and slabs have concrete with different $f_{c k}$ values to that of the columns, the concreting process should take place as follows: first, the columns must be concreted with the $f_{c k}$ concrete specified in the design so that this concrete fills part of the beam and slab, forming a sloping surface of approximately $45^{\circ}$ between the bottom of the beam and the top of the column. Subsequently, the beams and slabs are concreted with the $f_{c k}$ concrete specified in the design.

It is worth mentioning that all the advantages obtained in this study and mentioned above are supported by the use of a material with greater durability and useful life, in addition to other limitations that HSC provides with respect to conventional concretes.

\section{Bibliographic references}

[1] MEHTA, P.K; MONTEIRO, P.J.M. Concreto: estrutura, propriedades e materiais. $3^{\text {a }}$ edição, IBRACON, São Paulo, SP, 2008.

[2] TORRICO, F. A. Analise teórica e experimental do comportamento de pilares esbeltos de concreto de alta resistência, considerando a ductilidade. 345f. Tese (Doutorado em Engenharia de Estruturas) - Universidade de São Paulo, São Carlos, SP, 2010.

[3] AMERICAN CONCRETE INSTITUTE COMMITTEE, ACI 441R96: High-strength concrete columns: State-of-the-Art, ACI Structural Journal, Report, Vol 94, No. 3, pp. 323-335, 1997.

[4] MEHTA, P.K.; MONTEIRO, P. J. M. Concreto: estrutura, propriedades e materiais. $1^{\text {a }}$ ed. São Paulo, SP. Ed. Pini, 1994.

[5] COMITÉ EURO-INTERNATIONAL DU BÉTON. CEB-FIP Model Code 1990 - Design Code. Thomas Telford Services Ltda., July 1993. 
[6] AMERICAN CONCRETE INSTITUTE COMMITTEE, ACI 363R92: State-of-the-art Report on high-strength concrete, American Concrete Institute, Detroit, MI, September 1992, 55 pp.

[7] ASSOCIAÇÃO BRASILEIRA DE NORMAS TÉCNICAS, ABNT NBR 6118: Projeto de estruturas de concreto - Procedimento. Rio de Janeiro, RJ, 2014.

[8] ASSOCIAÇÃO BRASILEIRA DE NORMAS TÉCNICAS, ABNT NBR 8953: Concreto para fins estruturais - Classificação pela massa específica, por grupos de resistência e consistência. Rio de Janeiro, RJ, 2015.

[9] VANDERLEI, R. D. Análise experimental de pilares de concreto armado de alta resistência sob flexo-compressão reta. 183f. Dissertação (Mestrado em Engenharia de Estruturas) - Universidade de São Paulo, São Carlos, SP, 1999.

[10] CALDARONE, M. A. High-strength concrete - A practical guide. New York: New York, Editora Taylor \& Francis, 2009.

[11] PRADO, R. C. M. F. Comportamento estrutural de pilares curtos em concreto de alta resistência. 159 f. Dissertação (Mestrado em Engenharia de Estruturas) - Universidade Federal de Minas Gerais, Belo Horizonte, MG, 2001.

[12] ASSOCIAÇÃO BRASILEIRA DE NORMAS TÉCNICAS, ABNT NBR 6123: Forças devidas ao vento em edificações. Rio de Janeiro, RJ, 1988. 